\title{
Geographic variation and genetic relationships in populations of the Androniscus dentiger complex from Central Italy (Isopoda, Oniscidea, Trichoniscidae)
}

\author{
Gabriele Gentile and Giuliana Allegrucci *
}

\begin{abstract}
SUMMARY
Androniscus dentiger is a terrestrial isopod distributed from Great Britain to North Africa, inhabiting humid edafic environments, superficial underground compartments and both natural and artificial caves. In this study allozyme data have been used to investigate the geographic variation and the genetic relationships of several populations of A.dentiger from Central Italy, using as outgroups populations from four congeneric species, A.calcivagus, A.cfr.subterraneus, A.spelaeorum, and A.degener. Multivariate analysis of A. dentiger allele frequencies indicates the existence of a group of populations (group A) distributed in a wide geographic area which are genetically slightly differentiated, and several populations (arbitrarily defined as group B) which show differentiation levels comparable to those observed between the morphologically well differentiated species. The low valley of the river Tiber seems to act as an effective geographic barrier between the populations from group A and the remaining ones. The genetic divergence between populations within the group A seems to have a recent origin. This is suggested by the low genetic distances and heterozygosity values within the group A, and by the very low number of private alleles occurring in this group. The high degree of intraspecific and interspecific genetic differentiation is not consistent with the levels of morphological differentiation traditionally used to distinguish different species within this genus. On the whole, these data suggest that $A$. dentiger might be considered as a complex of cryptic/sibling species.
\end{abstract}

\section{INTRODUCTION}

The terrestrial isopod Androniscus dentiger inhabits, as other congeneric species, humid edafic environments, superficial underground compartments, and both natural and artificial caves. Usually, in Trichoniscidae, highly hygrophilic habits represent a strong constraint for dispersal. Evidence of this phenomenon is the high number of taxa (both at the species and genus level) which are geographically differentiated, and are also narrow endemics. A.dentiger, unlike other congeneric species and other Trichoniscidae, is widely distributed. It occurs in Great Britain, Central Europe, mainland Italy, Sicily, and North Africa and its range has been considered to be in a phase of active and passive (by man) expansion (Van-

* Dipartimento di Biologia, Università Tor Vergata, Viale della Ricerca Scientifica 00133 Roma - Italy. 
del, 1960). However, A. dentiger does not occur in Corsica (Taiti and Ferrara, 1996), Tuscanian archipelagos and in some localities along the Tuscanian coast (Taiti and Ferrara, 1980) where potentially colonizable environments occur. Moreover, this species is missing in many suitable caves within its range (Gentile, unpublished data).

In a previous study the levels of gene flow among populations of $A$. dentiger in Central Italy have been investigated using different $\mathrm{Nm}$ estimators. The very low levels of gene flow reported, even between neighboring populations, suggested that nearly all the populations studied have isolated gene pools (Gentile and Sbordoni, 1998). In this paper we discuss the geographic variation and the genetic relationships among the same $A$. dentiger populations, using as outgroups populations from four species belonging to the same genus.

\section{MATERIAL AND METHODS}

Twenty eight populations of $A$. dentiger from Central Italy have been studied, including cave and surface populations. Six populations taxonomically assigned to four different species (A. calcivagus, A. crf. subterraneus, A. spelaeorum and $A$. degener) were used as outgroups. These species are morphologically well differentiated (Vandel, 1960), and occur only in the North-Eastern Italian Prealpine mountains. Some of these species could also be found in syntopy. In these cases, no evidence of hybridization could be highlighted. In Table 1 the populations studied are reported. Cave and surface populations are indicated with a three letter symbol in upper and lower cases types, respectively.

Genetic variation was investigated using allozyme electrophoresis on cellulose acetate gels. The following enzymes were assayed: Ada, Aldo, Ca, Dia, Me, Aph, Pgm, ßGal, G6pd, Gpi, Got, Idh, Mdh, Mpi, Pep, Pk, for overall 19 gene loci scored. Details of the protocols used and allele frequencies are reported in Gentile and Sbordoni (1998).

Heterozygosity, Nei's (1972) and Reynolds' (Reynolds et. al., 1983) genetic distances were calculated using GEN-SURVEY (Vekemans and Lefebvre, 1997). We used the Nei's and Reynolds' indexes to provide more accurate dating of events of divergence in different evolutionary contexts. We used Nei's (1975) relationship $t=k D$, where $t$ is the time of divergence, $k$ (the substitution rate) is equal to $5^{*} 10^{6}$ and $D$ is the Nei's distance. Reynolds' index, which assumes divergence to be caused only by genetic drift, was used in a context of short-term evolution. We applied the formula $t \approx D / 2 N$, where $t$ is the time of divergence, $N$ the effective population size and $D$ is the Reynolds' coefficient. We estimated an average population size ranging from 500 to 5.000 individuals.

Table 1 - Sample sites 


\begin{tabular}{|c|c|c|c|c|c|c|c|}
\hline Species & Locality & Toponym & Altitude & Latitude & Longitude & Temp. $\left({ }^{\circ} \mathrm{C}\right)$ & Label \\
\hline A. dentiger & Croara, S.Lazzaro di Savena (BO) & Grotta della Spipola & 135 & $44^{\circ} 25^{\prime} 47^{\prime \prime}$ & $11^{\circ} 22^{\prime} 37^{\prime \prime}$ & 6,6 & SPI \\
\hline$"$ & Castelnuovo di Garfagnana (LU) & Tana di Magnano & 673 & $44^{\circ} 10^{\prime} 36^{\prime \prime}$ & $10^{\circ} 23^{\prime} 09^{\prime \prime}$ & 12,7 & MAG \\
\hline " & Piteglio, S.Marcello Pistoiese (PT) & Lana Termini & 340 & $44^{\circ} 02^{\prime} 27^{\prime \prime}$ & $10^{\circ} 43^{\prime} 17^{\prime \prime}$ & 11,8 & TER \\
\hline$"$ & Vecchiano (PI) & La Cantinaccia & 50 & $43^{\circ} 47^{\prime} 01^{\prime \prime}$ & $10^{\circ} 23^{\prime} 52^{\prime \prime}$ & 12,1 & can \\
\hline$"$ & Onferno,Gemmano (FO) & Grotta di Onferno & 304 & $43^{\circ} 52^{\prime} 19^{\prime \prime}$ & $12^{\circ} 32^{\prime} 32^{\prime \prime}$ & 13,2 & ONF \\
\hline$"$ & Tosi (FI) & Buca delle Fate & 465 & $43^{\circ} 48^{\prime} 00^{\prime \prime}$ & $11^{\circ} 27^{\prime} 00^{\prime \prime}$ & 11,5 & TOS \\
\hline$"$ & Livorno Montenero (LI) & Cava del Santuario & 193 & $43^{\circ} 29^{\prime} 00^{\prime \prime}$ & $10^{\circ} 21^{\prime} 00^{\prime \prime}$ & 14,6 & mon \\
\hline " & Piobbico, Monte Nerone (PS) & Grotta di Nerone & 1025 & $43^{\circ} 34^{\prime} 16^{\prime \prime}$ & $12^{\circ} 30^{\prime} 39^{\prime \prime}$ & 7,1 & NER \\
\hline$"$ & Vallombrosa (FI) & Fosso dei Bruciati & 830 & $43^{\circ} 44^{\prime} 00^{\prime \prime}$ & $11^{\circ} 34^{\prime} 00^{\prime \prime}$ & 10,3 & \\
\hline$"$ & Tecchie, Cantiano (PS) & Bosco di Tecchie & 650 & $43^{\circ} 26^{\prime} 00^{\prime \prime}$ & $12^{\circ} 40^{\prime} 00^{\prime \prime}$ & 11,7 & tec \\
\hline$"$ & Genga, S.Vittore (AN) & Grotta del Mezzogiomo & 350 & $43^{\circ} 24^{\prime} 08^{\prime \prime}$ & $12^{\circ} 57^{\prime} 10^{\prime \prime}$ & $12 ' 5$ & MEZ \\
\hline " & Gubbio, Monte Ingino (PG) & Grotta del Diavolo & 660 & $43^{\circ} 21^{\prime} 20^{\prime \prime}$ & $12^{\circ} 34^{\prime} 36^{\prime \prime}$ & 11,3 & DVL \\
\hline$"$ & Roccastrada, Belagaio (GR) & Tomba del Belagaio & 250 & $43^{\circ} 00^{\prime} 48^{\prime \prime}$ & $11^{\circ} 09^{\prime} 36^{\prime \prime}$ & $13^{\prime} 8$ & TOM \\
\hline$n$ & Sassopiano, Assisi (PG) & Grotta del Subasio & 1060 & $43^{\circ} 03^{\prime} 12^{\prime \prime}$ & $12^{\circ} 39^{\prime} 30^{\prime \prime}$ & 10,2 & SUB \\
\hline$"$ & Sarteano (SI) & Grotta dell'Orso & 516 & $42^{\circ} 59^{\prime} 59^{\prime \prime}$ & $11^{\circ} 51^{\prime} 42^{\prime \prime}$ & 14,2 & ORS \\
\hline$"$ & La Roccaccia, Titignano (TR) & la Piana & 260 & $42^{\circ} 44^{\prime} 19^{\prime \prime}$ & $12^{\circ} 19^{\prime} 29^{\prime \prime}$ & 10,5 & PIA \\
\hline$"$ & vitella del Tronto (TE) & Grotta & 605 & $42^{\circ} 45^{\prime} 20^{\prime \prime}$ & $1730^{m}$ & 13,6 & RIP \\
\hline$"$ & Il'Andreone, Spoleto (PG) & Grotta del Chiocchio & 705 & $42^{\circ} 40^{\prime} 58^{\prime \prime}$ & $10^{\prime} 03^{\prime \prime}$ & 11,7 & $\mathrm{CHI}$ \\
\hline$"$ & gelo (RI) & Rovine S.Vittorino & 45 & $2^{\prime} 00 "$ & $00^{\prime} 00^{\prime \prime}$ & 10,7 & vel \\
\hline$"$ & Vignanello (VT) & trusche & 320 & $42^{\circ} 22^{\prime} 00^{\prime \prime}$ & $12^{\circ} 19^{\prime} 00^{\prime \prime}$ & 12,1 & \\
\hline$"$ & Asserg & Grotte & 950 & $42^{\circ} 25^{\prime} 46^{\prime \prime}$ & $84^{\prime \prime}$ & 9,9 & mal \\
\hline$"$ & S.Demetrio nei Vestini (AQ) & di Stiffe & 695 & $42^{\circ} 15^{\prime} 10^{\prime \prime}$ & $13^{\circ} 32^{\prime} 22^{\prime \prime}$ & 10,4 & STI \\
\hline$"$ & Poggio Moiano (Rl) & Grotta La Pila & 831 & '20" & $5 ' 49^{\prime \prime}$ & 12,7 & PIL \\
\hline$"$ & chiano (RI) & Val di Varri & 806 & $42^{\circ} 12^{\prime} 34^{\prime \prime}$ & $13^{\circ} 09^{\prime} 05^{\prime \prime}$ & 10,9 & val \\
\hline$"$ & Popoli & Sorgenti del Pescara & 250 & $42^{\circ} 09^{\prime} 00^{\prime \prime}$ & $13^{\circ} 19^{\prime} 00^{\prime \prime}$ & 11 & pop \\
\hline$"$ & Monti della Duchessa (RI) & Valle Fua & 1050 & $42^{\circ} 10^{\prime} 00^{\prime \prime}$ & $13^{\circ} 18^{\prime} 00^{\prime \prime}$ & 12,1 & fua \\
\hline n & Anticoli Corrado (RM) & Rive dell'Anie & & $42^{\circ} 01^{\prime} 00^{\prime \prime}$ & $13^{\circ} 00^{\prime} 00^{\prime \prime}$ & 10,5 & ant \\
\hline$"$ & Lazio (FR) & za del Trevi & 600 & $41^{\circ} 51^{\prime} 18^{\prime \prime}$ & $13^{\circ} 12^{\prime} 35^{\prime \prime}$ & 9,8 & TRV \\
\hline A. calcivagus & Caprino Bergamasco (BG) & Büs del Böter & 550 & $45^{\circ} 45^{\prime} 00^{\prime \prime}$ & $09^{\circ} 29^{\prime} 00^{\prime \prime}$ & 10,2 & BOT \\
\hline & Villa di Serio (BG) & Miniere di Villa & 31 & $45^{\circ} 43^{\prime} 00^{\prime \prime}$ & $09^{\circ} 44^{\prime} 00^{\prime \prime}$ & 13,6 & MIN \\
\hline$"$ & Zandobbio (BG) & Lega Casina Melania & 47 & $45^{\circ} 41^{\prime} 00^{\prime \prime}$ & $09^{\circ} 55^{\prime} 00^{\prime \prime}$ & 10,7 & LAG \\
\hline A. subterraneus & S.Anna d'Alfaedo, Veja (VR) & Grotta A Ponte di Veja & 58 & $45^{\circ} 36^{\prime} 28^{\prime \prime}$ & $10^{\circ} 58^{\prime} 06^{\prime \prime}$ & 10,7 & \\
\hline A. spelaeroum & Roccolino, Rota d'Imagna (BG) & Tomba dei Polacchi & 565 & $45^{\circ} 50^{\prime} 00^{\prime \prime}$ & $09^{\circ} 30^{\prime} 00^{\prime \prime}$ & 9,4 & POL \\
\hline A. degener & S.Anna d'Alfaedo, Veja (VR) & Grotta A Ponte di Veja & 580 & $45^{\circ} 36^{\prime} 28^{\prime \prime}$ & $10^{\circ} 58^{\prime} 06^{n}$ & 10,7 & Yl \\
\hline
\end{tabular}

Statistical significance of heterozygosity estimates and genetic distances between and within groups of populations was tested by 1000 bootstrap cycles over populations (Van Rossum et al., 1997; Vekemans and Lefebvre, 1997). The program GENETIX ver. 3.0 (Belkhir et al., 1996) was used to test the null hypothesis $D=0$ for each pair of populations.

An ordination of $A$. dentiger populations was carried out by means of the Factorial Correspondence Analysis carried out on allele frequencies (FCA, Benzecrì et al., 1973). A geographic contour map was obtained by interpolating the scores of the first axis of the Factorial Correspondence Analisys (Cavalli-Sforza et al., 1994).

The neighbor-joining (NJ tree, Saitou and Nei, 1987) method was applied to a matrix of genetic distances (Nei, 1972). Robustness of each node was evaluated by bootstrapping allele frequencies 1000 times, using the program SEQBOOT in PHYLIP 3.57 (Felsenstein, 1995).

We also carried out parsimony analyses on allozyme data. Allozymes were recoded considering a locus as a character, and a combination of alleles occurring at that locus as a state (Mabee and Humphries, 1993). In- 
stead of ordering the character states and imposing a specific pathway, we considered all transformations to be possible. In a stepmatrix, a cost to every possible transformation was assigned by assuming that each gain or loss of an allele equals one evolutionary step. We used ASAP 1.5 (Thumfort and Sampson, personal communication) to recode allozyme data according to the procedure assessed in Mardulyn and Pasteels (1994). Most-parsimoniuos (MP) trees were derived by the heuristic search as implemented in PAUP 3.1.1 (Swofford, 1993). Ten random replicates of a heuristic search were performed. The options random and tree-bisection-reconnection (TBR) were used for stepwise addition and branch swapping procedures, respectively. The MP tree and the shortest trees supporting alternative phylogenetic hypotheses were compared using Templeton's (1983) test, as detailed in Larson (1994).

\section{RESULTS}

Figure 1 shows the results of the Factorial Correspondence Analysis carried out on allele frequencies of the 28 populations of A.dentiger. The first axis which explained $24.5 \%$ of variance allowed the discrimination between two major groups: group A, including populations distributed in a wide area ranging from the Apennines of Tuscany and Marches to the alluvial plains of Tuscany and Latium, and the group B including the remaining populations. The second axis (13\%) clearly separates STI and PIA populations from all the others, while the third axis $(10.2 \%)$ discriminated populations DVL, PIA, SUB and CHI. The second and third axis indicated that the Apennines populations do not form an homogeneous group.

Alternative alleles and a high number of private alleles occurred in most loci. In the Figure 2 the percentage of alleles which are shared by an increasing number of populations (represented by histograms) is reported together with their average frequency (represented by line). More than $40 \%$ of all alleles scored are shared by a maximum of three populations. These alleles showed an average frequency equal to 0.4 .

Only two private alleles occurred in the group A, while 11 private alleles were found in the group B. Nearly all the alleles shared only by two and three populations were in group B.

Mean heterozygosity per population is reported in Table 2. Average heterozygơsity estimates between and within groups $\mathrm{A}$ and $\mathrm{B}$ are reported in Tables $3 \mathrm{a}$ and $3 \mathrm{~b}$. We did not observe a statistically significant difference in mean heterozygosity between cave and surface populations. However, if groups A and B were analyzed separately, heterozygosity levels were statistically different between cave and surface populations within the group B. 


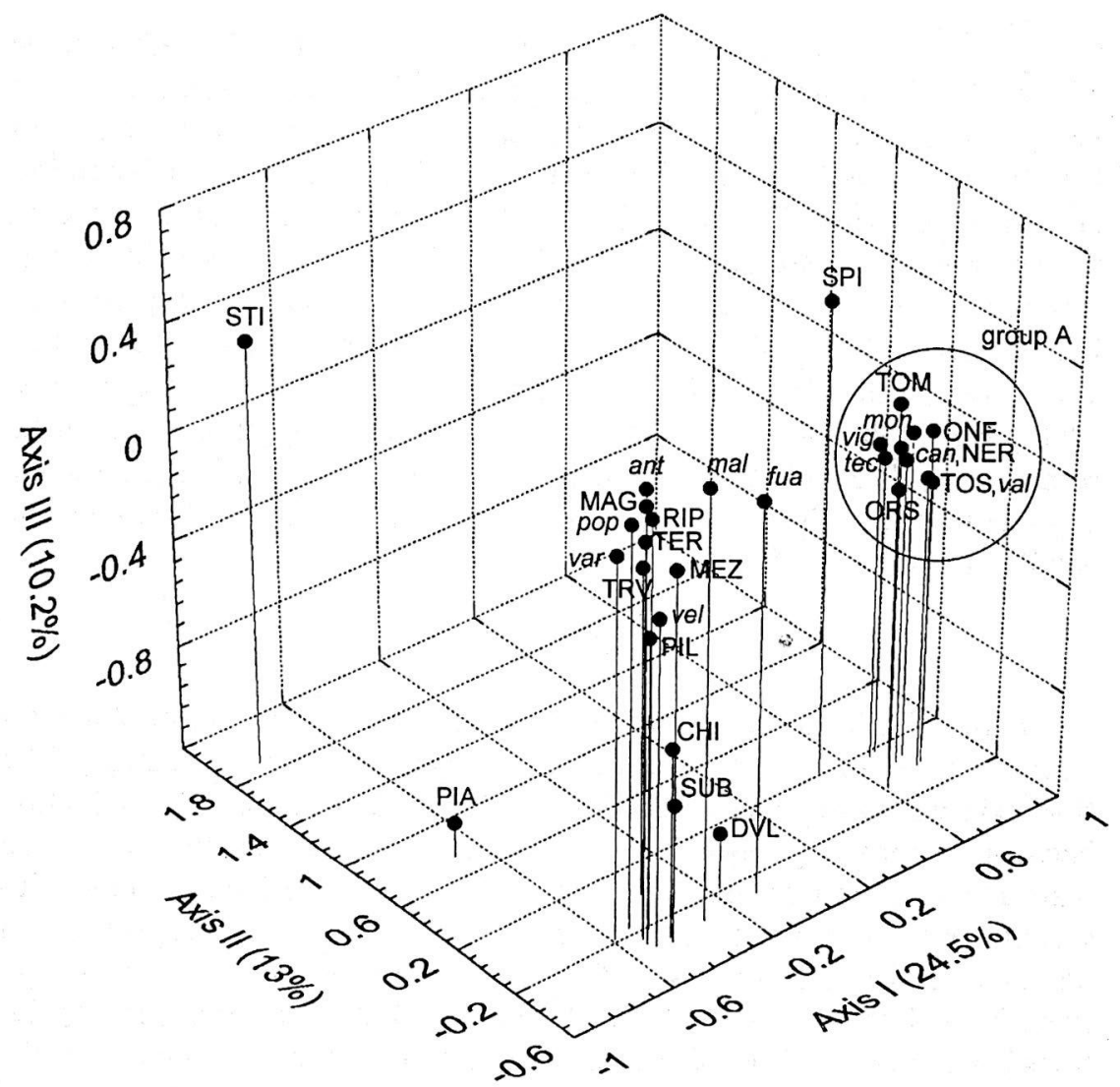

Fig. 1 - Factorial Correspondence Analysis on allele frequencies at 18 polymorphic loci in $A$. dentiger. The first three axis are represented.

Nei's genetic distances are reported in the Appendix. Genetic distances between and within groups $\mathrm{A}$ and $\mathrm{B}$ are summarized in Tables 3 and 4 . Within A. dentiger intraspecific genetic distance values between populations are generally high, with an average of $0.493 \pm 0.013$. The genetic distance between group A and group B is very high $(D=0.670 ; p=0.000)$.

Interspecific distances ranged from 0.3 to 1.539 , with a mean of 0.749 \pm 0.019. A. cfr. subterraneus has the smallest distance value from A.dentiger $(D=0.578 \pm 0.027)$, whereas A. degener has the highest one $(D=1.093 \pm 0.040)$. Average $D$ values from $A$. dentiger and the two remaining species, $A$. calcivagus and A. spelaeorum, are $0.680 \pm 0.020$ and $0.683 \pm 0.023$, respectively. 
The topology of the NJ tree obtained is shown in Fig.3a. The tree is arbitrarily rooted at $A$. degener (VJ1), the most differentiated species. A. dentiger splits into the groups $\mathrm{A}$ and $\mathrm{B}$, being divided by A. calcivagus. A. calcivagus is the only robust cluster of the whole tree (bootstrap values $>70 \%$ ). The remaining two species, A. cfr. subterraneus and A. spelaeorum, link together and are nested with group $B$.

Table 2 - Genetic variability at 19 loci in the 34 populations of Androniscus.

\begin{tabular}{|c|c|c|c|c|}
\hline \multirow[b]{2}{*}{ Population } & \multirow{2}{*}{$\begin{array}{l}\text { Mean no. } \\
\text { of alleles } \\
\text { per locus }\end{array}$} & \multirow{2}{*}{$\begin{array}{c}\begin{array}{c}\text { Percentage } \\
\text { of loci } \\
\text { polymorphic(*) }\end{array} \\
\end{array}$} & \multicolumn{2}{|c|}{ Mean heterozygosity } \\
\hline & & & Observed & Expected \\
\hline \multicolumn{5}{|c|}{ Androniscus dentiger } \\
\hline SPI & $1.6 \pm 0.1$ & 26,3 & $0.069 \pm 0.024$ & $0.069 \pm 0.025$ \\
\hline MAG & $1.7 \pm 0.1$ & 42,1 & $0.123 \pm 0.034$ & $0.138 \pm 0.038$ \\
\hline TER & $1.7 \pm 0.1$ & 26,3 & $0.147 \pm 0.051$ & $0.123 \pm 0.040$ \\
\hline can & $1.4 \pm 0.1$ & 21,1 & $0.087 \pm 0.035$ & $0.090 \pm 0.037$ \\
\hline ONF & $1.3 \pm 0.1$ & 15,8 & $0.072 \pm 0.039$ & $0.064 \pm 0.034$ \\
\hline TOS & $1.5 \pm 0.1$ & 26,3 & $0.084 \pm 0.032$ & $0.083 \pm 0.032$ \\
\hline mon & $1.5 \pm 0.1$ & 36,8 & $0.100 \pm 0.037$ & $0.104 \pm 0.036$ \\
\hline NER & $1.6 \pm 0.1$ & 36,8 & $0.101 \pm 0.037$ & $0.108 \pm 0.037$ \\
\hline val & $1.4 \pm 0.1$ & 42,1 & $0.094 \pm 0.030$ & $0.093 \pm 0.031$ \\
\hline tec & $1.5 \pm 0.1$ & 36,8 & $0.101 \pm 0.032$ & $0.111 \pm 0.036$ \\
\hline MEZ & $1.5 \pm 0.1$ & 26,3 & $0.088 \pm 0.032$ & $0.089 \pm 0.033$ \\
\hline DVL & $1.4 \pm 0.1$ & 15,8 & $0.069 \pm 0.030$ & $0.066 \pm 0.028$ \\
\hline TOM & $1.2 \pm 0.1$ & 15,8 & $0.062 \pm 0.035$ & $0.058 \pm 0.033$ \\
\hline SUB & $1.7 \pm 0.2$ & 52,6 & $0.158 \pm 0.043$ & $0.169 \pm 0.047$ \\
\hline ORS & $1.5 \pm 0.1$ & 31,6 & $0.089 \pm 0.028$ & $0.101 \pm 0.034$ \\
\hline PIA & $1.5 \pm 0.1$ & 42,1 & $0.130 \pm 0.037$ & $0.151 \pm 0.043$ \\
\hline RIP & $1.3 \pm 0.1$ & 21,1 & $0.072 \pm 0.040$ & $0.066 \pm 0.031$ \\
\hline $\mathrm{CHI}$ & $1.3 \pm 0.1$ & 21,1 & $0.087 \pm 0.040$ & $0.083 \pm 0.037$ \\
\hline vel & $1.9 \pm 0.2$ & 47,4 & $0.169 \pm 0.042$ & $0.169 \pm 0.043$ \\
\hline vig & $1.5 \pm 0.1$ & 31,6 & $0.062 \pm 0.018$ & $0.062 \pm 0.018$ \\
\hline mal & $1.5 \pm 0.1$ & 36,8 & $0.125 \pm 0.039$ & $0.119 \pm 0.036$ \\
\hline STI & $1.3 \pm 0.1$ & 10,5 & $0.029 \pm 0.018$ & $0.027 \pm 0.016$ \\
\hline PIL & $1.5 \pm 0.1$ & 26,3 & $0.062 \pm 0.021$ & $0.068 \pm 0.023$ \\
\hline var & $1.7 \pm 0.2$ & 26,3 & $0.115 \pm 0.040$ & $0.113 \pm 0.040$ \\
\hline pop & $1.5 \pm 0.1$ & 21,1 & $0.108 \pm 0.044$ & $0.104 \pm 0.041$ \\
\hline fua & $1.6 \pm 0.2$ & 36,8 & $0.118 \pm 0.040$ & $0.127 \pm 0.044$ \\
\hline ant & $1.7 \pm 0.2$ & 36,8 & $0.141 \pm 0.043$ & $0.158 \pm 0.048$ \\
\hline TRV & $1.6 \pm 0.2$ & 36,8 & $0.120 \pm 0.041$ & $0.132 \pm 0.043$ \\
\hline \multicolumn{5}{|c|}{ Androniscus calcivagus } \\
\hline BOT & $1.5 \pm 0.1$ & 21,1 & $0.084 \pm 0.040$ & $0.074 \pm 0.033$ \\
\hline MIN & $2.0 \pm 0.2$ & 47,4 & $0.151 \pm 0.036$ & $0.178 \pm 0.045$ \\
\hline LAG & $1.6 \pm 0.1$ & 42,1 & $0.125 \pm 0.038$ & $0.127 \pm 0.041$ \\
\hline \multicolumn{5}{|c|}{ Androniscus cfr. subterraneus } \\
\hline VJ2 & $1.4 \pm 0.1$ & 21,1 & $0.051 \pm 0.021$ & $0.060 \pm 0.027$ \\
\hline \multicolumn{5}{|c|}{ Andronișcus spelaeorum } \\
\hline POL & $1.4 \pm 0.1$ & 26,3 & $0.095 \pm 0.040$ & $0.097 \pm 0.037$ \\
\hline \multicolumn{5}{|c|}{ Androniscus degener } \\
\hline VJ1 & $1.5 \pm 0.1$ & 31,6 & $0.066 \pm 0.020$ & $0.062 \pm 0.018$ \\
\hline
\end{tabular}

(*) A locus is considered polymorphic if the frequency of the most common allele does not exceed 0.95 


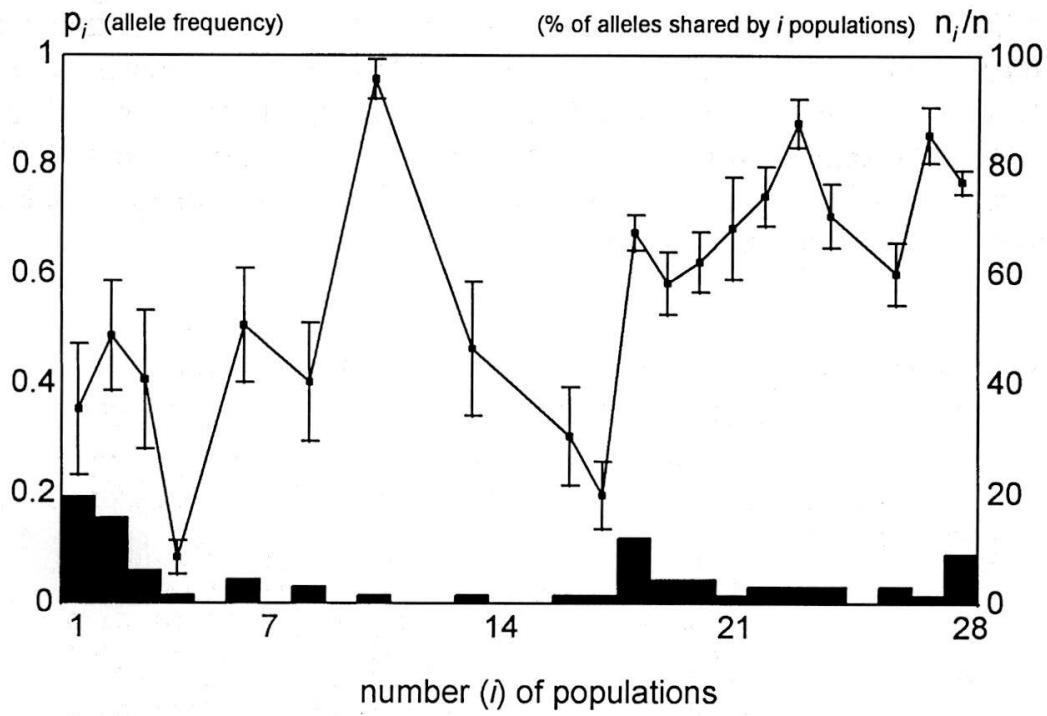

Fig. 2 - Genetic differentiation in Androniscus dentiger. Bars indicate the percentage $\left(\mathrm{n}_{i} / \mathrm{n}\right)$ of alleles ( $\mathrm{n}=67$ alleles scored) shared by an increasing number of populations $(i)$, up to 28 . Whiskers represent standard error of average frequency $(p i)$ of alleles shared by populations at each $i$ classes.

The parsimony analysis produced 112 equally parsimonious trees (length=252). The MP tree is reported in Figure $3 \mathrm{~b}$. It is also rooted at $A$. degener (VJ1), and shows that $A$. dentiger splits into two different groups of populations, mainly corresponding to the groups A and B obtained by FCA, and the NJ tree. Groups A (plus SPI) and B are separated by the insertion of $A$. calcivagus and A. spelaeorum. A. cfr. subterraneus is nested with group B. We used Templeton's (1983) test to determine whether we could reject the hypothesis of the monophyletic origin of A. dentiger. We compared the MP tree to the most parsimonious tree obtained by forcing the monophyly of $A$. dentiger. The tree with $A$. dentiger monophyletic required 5 steps more than the MP tree. However, it was not significantly different from the MP tree.

\section{DISCUSSION}

\section{Geographic variation and evolutionary patterns}

Multivariate analysis (fca) of allele frequencies (Fig. 1) pointed out the existence of at least two groups of populations. The populations belonging to group $\mathrm{A}$ are strongly divergent from the remaining ones (group B). In the 
South, the low valley of the river Tiber divides the two groups and might have represented a notable barrier to gene flow. Interestingly, the Tiber valley also represents a geographical barrier between populations belonging to the cave crickets Dolichopoda laetitiae-geniculata complex (Cesaroni et al., 1997).

Groups A and B show different geographical distribution an even very different evolutionary patterns. In group A the number of private alleles is low, suggesting that mutation did not play an important role in the evolutionary process within this group. Average genetic distances (Nei's index) within group A (Tables 3a,b; 4) suggest that the times of divergence between most of the A. dentiger populations within group A are very recent. The Reynolds' coefficient relates the divergence times within group A to a time-span ranging between 17,000 and 1,700 years ago. This estimate would correspond to the wide expansion in Central Italy of the mesophilic forests, which represent the main routes for dispersal of $A$. dentiger. This expansion started at the beginning of the Holocene (14.000 years ago) until the present (Magri and Follieri, 1992), after a long period (300.000 years) when mesophilic forest environments occurred in very few and short periods, and were limited to very narrow areas (Follieri et al., 1993). This scenario may explain the absence of $A$. dentiger in the whole of the tuscanian archipelagos and in the tuscanian coastal mountains (Taiti and Ferrara, 1980), which were connected with the mainland only in the last 10.000 years (Lanza, 1984).

Figure 4 shows a geographic representation of the genetic variation observed. The darkest area groups the most similar populations belonging to group A. It might be the possible area from which propagules from a limited number of populations started the colonization of the alluvial lands of Tuscany. Genetic drift might be responsible for the decreased genetic variability within new populations, where alleles which are rare in the source populations are less likely to be represented. Consistently with the hypothesis of a recent colonization, average genetic distance among surface populations within group A is comparable with the value obtained for cave ones (Tables $3 a, b)$.

Mutation seems to be one of the main factors shaping the evolutionary pattern within group B. In this group in fact, the number of private alleles is high. The wide range of genetic distances within group B suggested that most of the splitting events within this group seem to have occurred in a wide timespan, which can be dated back to climatic shifts and marine transgressions during the Pliocene-Pleistocene glaciations. Extinctions and recolonizations during several glaciation episodes in the last Pliocene and during the Quaternary could explain both the observed lack of $A$. dentiger in many potentially colonizable habitats within its area and the varying degrees of genetic differentiation observed in the group B. Since these processes are much older than 
the colonization by populations of group A, we would expect the populations from group B to have partly rebuilt their genetic variability. Indeed, we did observe a statistically significantly higher heterozygosity in the populations from group B than from group A (Mann-Whitney Z=2.07; $p<<0.05$ at twotailed test). Furthermore, surface and cave populations of group B are also differentiated. Within group B, surface populations show a higher level of average heterozygosity than the value observed in the cave ones, which is in turn comparable to the value observed in group A (Tables 3a,b). So, in group B, increasing genetic variability occurred in surface populations only, while cave populations seem to be influenced by the effects of genetic drift or by some form of stabilizing selection. This scenario is consistent with the genetic distance values observed. In fact, group A and B are genetically distinct (Table 4 ), and in group B average genetic distance among cave populations is much higher than the value observed for surface ones (Tables 3a,b).

The geographical patterns of alleles shared by two and three populations might be interpreted as a trace of an ancestral polymorphism reduced by genetic drift due to extinction dynamics (Gentile and Sbordoni, 1998). In fact, the higher the number of populations sharing the same allele, the more unlikely it is that this allele arose by recurrent mutation in those populations. Populations sharing these alleles are separated by geographic distances up to $250 \mathrm{Km}$, suggesting that extinction events might have occurred over a wide geographic scale.

Table $3 \mathrm{a}-$ Level of population diversity within groups A and B: Average genetic distances $\left(\mathrm{Nei}_{72}\right)$ and observed heterozygosity within cave and surface populations.

\begin{tabular}{lllll}
\hline & Cave (A) & Surface $(A)$ & Cave (B) & Surface (B) \\
\hline$D\left(\mathrm{Nei}_{72}\right)$ & 0.141 & 0.105 & 0.465 & 0.186 \\
$H_{0}$ & 0.082 & 0.089 & 0.096 & 0.129 \\
\hline
\end{tabular}

Table $3 \mathrm{~b}$ - Differences $(\Delta)$ between levels of population diversity within groups $\mathrm{A}$ and $\mathrm{B}$ : The upper values is the triangular matrix are $\Delta D$; the lower ones are $\Delta H_{0}$.

\begin{tabular}{llll}
\hline & Cave $(\mathrm{A})$ & Surface $(\mathrm{A})$ & Cave $(\mathrm{B})$ \\
\hline Surface $(\mathrm{A})$ & $0.036 \mathrm{~ns}$ & & \\
& $0.008 \mathrm{~ns}$ & & \\
Cave (B) & $0.324^{\star \star}$ & $0.360^{\star \star}$ & \\
& $0.015 \mathrm{~ns}$ & $0.007 \mathrm{~ns}$ & \\
Surface (B) & $0.045 \mathrm{~ns}$ & $0.081^{\star}$ & $0.279^{* \star}$ \\
& $0.047^{\star \star}$ & $0.040^{\star \star}$ & $0.033^{*}$ \\
\hline
\end{tabular}

(*) $p[\Delta=0]<0.05 ;\left(^{\star \star}\right) p[\Delta=0]<0.01$ 
Table 4 - Level of population differentiation between groups A and B: Average genetic distances $\left(\mathrm{Nei}{ }_{72}\right)$ between cave and surface populations

\begin{tabular}{llll}
\hline & Cave (A) & Surface (A) & Cave (B) \\
\hline Surface (A) & $0.118 \mathrm{~ns}$ & & \\
Cave (B) & $0.710^{\star \star}$ & $0.671^{\star \star}$ & $0.371^{\star}$ \\
Surface (B) & $0.624^{\star \star}$ & $0.633^{\star \star}$ & \\
\hline
\end{tabular}

(*) $p[D=0]<0.05 ;(* *) p[D=0]<0.01$

\section{Genetic relationships}

The genetic distances between populations morphologically belonging to A.dentiger show a wide spectrum of values, including many values higher than 1. Thorpe (1983) suggested that genetic distance values higher than 0.163 between allopatric populations indicate that they belong to different species. If we accept this suggestion, most populations of $A$. dentiger are different species. As already pointed out (Lessios and Weinberg, 1994) there is no theoretical reason to consider the cut-off value indicated by Thorpe as an unambiguous threshold for speciation. The inclusion of species morphologically differentiated as outgroups allows us to calibrate the amount of genetic divergence that can be revealed by allozyme data, providing a "within taxon" standard which is useful to establish a threshold for speciation. Most of the average genetic distances between Androniscus species are of the same order of magnitude as many distances between populations of $A$. dentiger.

In contrast with the high degree of genetic divergence, morphological differentiation in A.dentiger does not show a degree of geographic variation useful to study the systematic relationships among populations (Vandel, 1960; Gentile, 1994).

In the last twenty years the number of cryptic/sibling species which have been claimed to occur in various taxa is greatly increased. Genetic, ecological and behavioral data are often used and sometimes combined to test the actual differentiation between putative species. In particular, most genetic studies of cave dwelling isopods, both aquatic and terrestrial, revealed the occurrence of high genetic distance values between morphologically indistinguishable populations as reported from studies on Typhlocirolana (Caccone et al., 1986), Stenasellus (Messana et al., 1995), Oritoniscus (Cobolli Sbordoni et al., 1995) and Trichoniscus (Cobolli Sbordoni et al., 1997). Since it has been possible to evidenciate that reproductive isolation may occur in allopatry as a by-product of a high degree of genetic differentiation (Coyne and Orr, 1989), it would appear reasonable that speciation events may occur more frequently than has been though. The high levels of genetic divergence we observed suggest that $A$. dentiger could be probably considered as a complex of cryp- 
ticlsibling species. We could identify two genetically differentiated groups of populations (A and B). Additionally, in the group B, most of genetic distances observed between populations are much higher than the values reported for morphologically distinguishable species. However it remains to be assessed how many species $A$. dentiger complex might include. This appears to be a difficult task, since breeding experiments carried out on other Peracarids showed that the paradigm "high genetic distance - high degree of reproductive isolation" does not hold always (Scheepmaker, 1990).
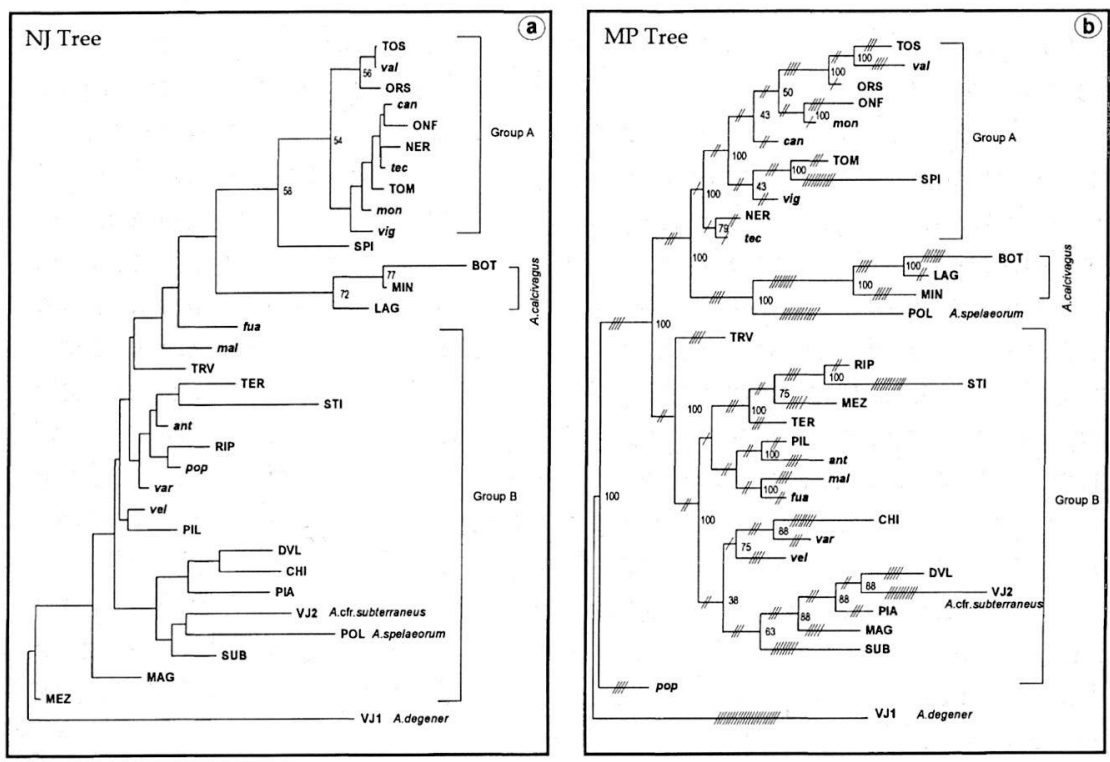

Fig. 3 - Genetic relationships between Androniscus species. a) Neigbbor-join (NJ) tree. The number at the nodes of $\mathrm{NJ}$ is the number of times the cluster at the right of the node occurs out of 100 bootstrap repetitions. Only bootstrap values higher than $50 \%$ are shown, b) Maximum parsimony tree (MP). The number at the nodes of MP is the number of times (percent) that the cluster at the right of the node occurs out of all most parsimonious trees found. Slashes represent the changes of character states between two contiguous nodes.

Both the $\mathrm{NJ}$ tree, and the parsimony analysis are in agreement with the multivariate analysis (FCA). However, neither NJ or MP tree (Fig. 3) is helpful to assess the genetic relationships between the different species of $A n$ droniscus studied. They suggest that $A$. dentiger is polyphyletic. However, bootstrapping and Templeton's test do not support the polyphyletic origin of $A$. dentiger, which indeed appears to be unreasonable even from a biogeographical point of view. In fact, among all the Androniscus (Dentigero- 


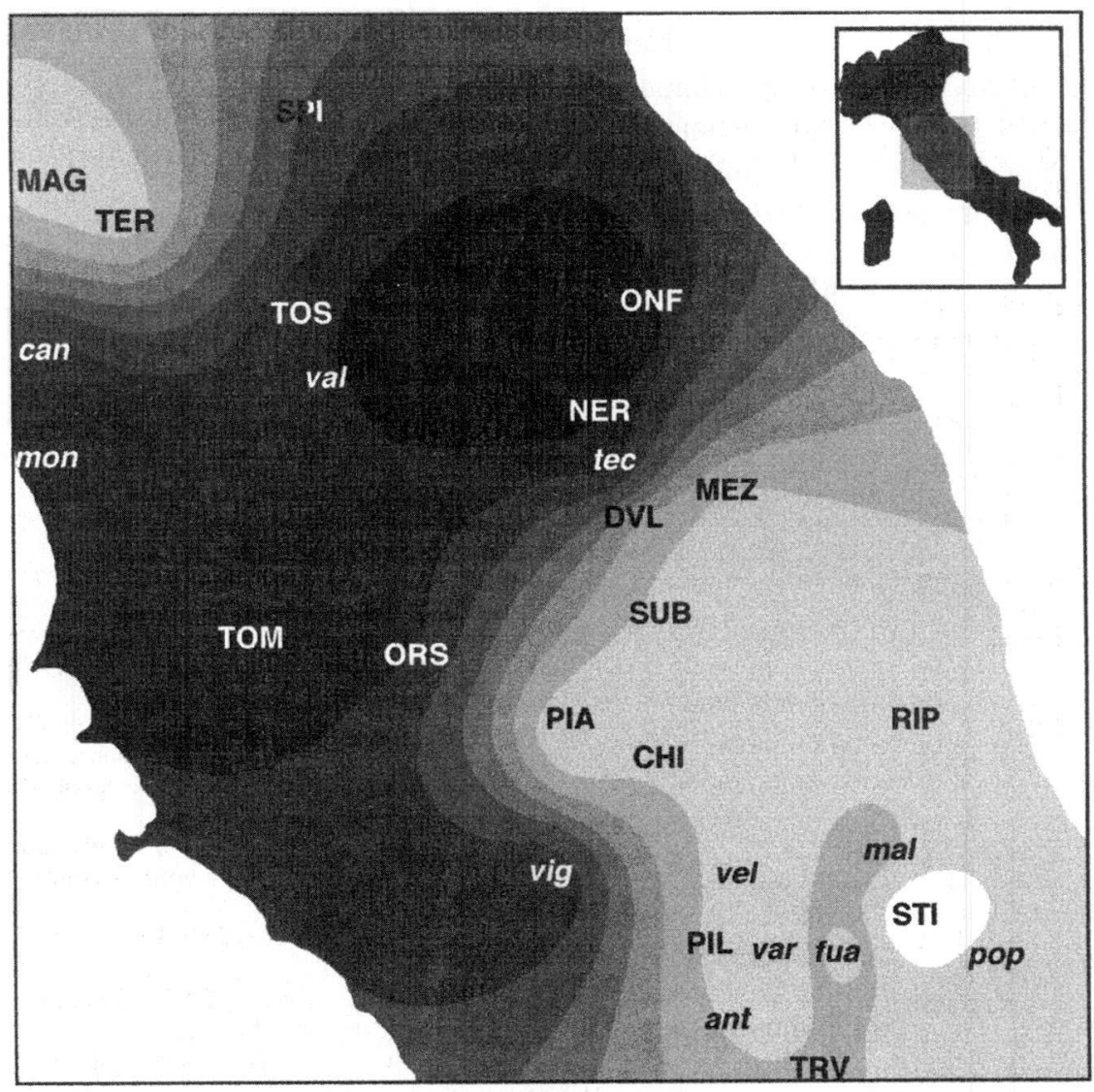

Fig. 4 - Geographic variation of allele frequencies in A. dentiger of Central Italy. The contour map has been obtained by interpolating the values of the coordinates on the first axis after a Factorial Correspondence Analysis. Each tone of color corresponds to an increment equal to 0.2 on the first axis. The dark area identifies the group A, while group B is represented by the white area (Redesigned from Gentile, 1998).

niscus) species, only A. dentiger occurs in Central Italy, the range of the other congeneric species being strictly limited to the North and NorthEastern Prealps. The difficulty to assess robust genetic relationships between populations and species of Androniscus might be explained by the high degree of genetic differentiation found.

Further investigations by using a better addressed genetic marker will probably be necessary to investigate the phylogenetic relationships among the species belonging to this genus. 


\section{ACKNOWLEDGMENTS}

Results discussed in this paper are part of Ph.D. thesis of G. Gentile. We are grateful to R. Argano and A. Caccone for reading and discussing an early version of this paper, allowing us to improve it. We are indebted with V. Sbordoni for his criticism and his support in this research.

\section{REFERENCES}

BELKHIR, K., P. BORSA, J. GOUDET, L. CHIKHI, and F. BONHOMME. 1996. GENETIX, logiciel sous Windows TM pour la génétique des populations. Release 3.0. Laboratoire Génome et Populations, CNRS UPR 9060, Université Montpellier 2, Montpellier.

BENZECRİ, J.P. et al. 1973. L'analyse des donnes. II. L'analyse des correspondences. Du$\operatorname{nod}($ ed.). Paris.

CACCONE, A., G. ALLEGRUCCI, D. CESARONI, M. COBOLLI SBORDONI, E. DE MATTHAEIS, G. LA ROSA, and V. SBORDONI. 1986. Genetic variability and divergence between cave dwelling populations of Typhlocirolana (Crustacea, Isopoda) from Majorca and Sicily. Bioch. Syst. Ecol. 14: 215-221.

CAVALLI-SFORZA, L.L., P. MENOZZI and A. PIAZZA. 1994. The history and geography of human genes, pp.1088. Princeton University Press.

CESARONI, D., P. MATARAZZO, G. ALLEGRUCCI, and V. SBORDONI. 1997. Comparing patterns of geographic variation in cave crickets by combining geostatic methods and Mantel tests. J. Biogeog. 24: 419-431.

COBOLLI SBORDONI, M., S. TAITI, E. DE MATTHAEIS, and V. KETMAIER. 1995. Genetic relationships among populations of the Oritoniscus paganus group (Crustacea, Isopoda, Oniscidea) from Corsica and Giannutri (Tuscan Archipelago). Mém. Biospéol. 22: $13-16$.

COBOLLI SBORDONI, M., V. KETMAIER, E. DE MATTHAEIS, and S. TAITI 1997. Biochemical systematics and evolutionary relationships in the Trichoniscus pusillus complex (Crustacea, Isopoda, Oniscidea). Heredity 79: 463-472.

COYNE, J. A. and H. A. ORR. 1989. Patterns of speciation in Drosophila. Evolution 43: 362-381.

FELSESTEIN, J. 1995. PHYLIP (Phylogeny Inference Package). Release 3.57c. Distributed by the Author. Department of Genetics. University of Washington. Seattle.

FOLLIERI, M., D. MAGRI, and B. NARCISI. 1993. Paleoenvironmental investigations on long sediment cores from volcanic lakes of Lazio (Central Italy) - An overview. In: NEGENDANK, J. F. W. and ZOLITSCHKA, B. (eds.). Paleolimnology of European Maar Lakes. Lecture Notes in Earth Sciences, pp. 95-107. Springer Verlag, Berlin.

GENTILE, G. 1994. Struttura genetica di popolazioni e variazione geografica nell'isopode terrestre Androniscus dentiger dell'Italia Centrale (Isopoda, Oniscidea, Trichoniscidae). $\mathrm{Ph}$. D. Thesis, University "Tor Vergata" Rome, Italy.

GENTILE, G. 1998. Gli eventi paleoclimatici del Quaternario in Italia Centrale: il modello biogeografico di Androniscus dentiger (Oniscidea, Trichoniscidae). Soc. Ital. Biogeogr. h.s. 19-1997: 145-156.

GENTILE, G. and V. SBORDONI. 1998. Indirect methods to estimate gene flow in cave and surface populations of Androniscus dentiger (Isopoda, Oniscidea). Evolution 52: 432 442.

LANZA, B. 1984. Sul significato biogeografico delle isole fossili, con particolare riferimento all'Arcipelago pliocenico della Toscana. Atti Soc. It. Sci. Nat., 125: 145-158.

LARSON, A. 1994. The comparison of morphological and molecular data in phylogenetic systematics. In:. SCHIERWATER, B., STREIT, B., WAGNER, G.P. and DESALLE R. (eds.) Molecular ecology and evolution: Approaches and applications, pp. 371-390. Birkhäuser Verlag, Basel.

LESSIOS, H. A. and J. R. WEINBERG. 1994. Genetic and morphological divergence among morphotypes of the isopod Excirolana on the two sides of the Isthmus of Panama. Evolution 48: 530-548. 
MABEE, P. M. and J. HUMPHRIES. 1993. Coding polymorphic data. Syst. Biol. 42: 166181.

MAGRI, D. and M. FOLLIERI. 1992. Transitions from interglacial to glacial in the pollen record from Valle di Castiglione (Roma). In: NATO ASI series 1, KUKLA, G. J. and WENT E. (eds.). Global Environmental Change. Start of a glacial, pp. 23-36. Springer Verlag, Berlin.

MARDULYN, P. and J. M. PASTEELS. 1994. Coding allozyme data using stepmatrices: defining new original states for the ancestral taxa. Syst. Biol. 43: 567-572.

MESSANA, G., M. COBOLLI SBORDONI, E. DE MATTHAEIS, V. KETMAIER, and R. ARGANO. 1995. A preliminary essay on the biogeography of Italian stenasellids. Mém.Biospéol. 22: 109-114.

NEI, M. 1972. Genetic distance between populations. Am. Nat. 106: 283-292.

NEI, M. 1975. Molecular Population Genetics and Evolution. North-Holland. Amsterdam.

REYNOLDS, J., B.S. WEIR, and C.C. COCKERHAM. 1983. Estimation of the coancestry coefficient basis for a short-term genetic distance. Genetics 105: 767-779.

SAITOU, N. and M. NEI. 1987. The neighbour-joining method: A new method for reconstructing phylogenetic trees. Mol. Biol. Evol. 4: 406-425.

SCHEEPMAKER, M. 1990. Genetic differentiation and estimated levels of gene flow in members of the Gammarus pulex-group (Crustacea, Amphipoda) in Western Europe. Bijdragen tot de Dierkunde 60: 3-30.

SWOFFORD, D. 1993. PAUP: Phylogenetic analysis using parsimony. Release 3.1.1s. Illinois Natural History Survey, Champaign.

TAITI, S. and F. FERRARA. 1980. Nuovi studi sugli isopodi terrestri dell'Arcipelago toscano. Redia 63: 249-300.

TAITI, S. and F. FERRARA. 1996. Terrestrial Isopoda of Corsica (Crustacea, Oniscidea). Bull. Mus. Nat. Hist. Nat. Paris 18: 459-545.

TEMPLETON, A. 1983. Phylogenetic inference from restriction andonuclease cleavage site maps with particular reference to evolution of humans and apes. Evolution 37: 221-244.

THORPE, J.P. 1983. Enzyme variation, genetic distance and evolutionary divergence in relation to levels of taxonomic separation. In: OXFORD, G.S. and ROLLINSONS, D.(eds.). Protein polymorphism: adaptive and taxonomic significance, pp. 131-152. Academic Press, London.

VANDEL, A. 1960. Les espéces d'Androniscus Verhoeff, 1908 appartenant au sousgenre Dentigeroniscus Arcangeli, 1940 (Crustacés: Isopodes terrestres). Ann. Spéléol. 15: 553584.

VAN ROSSUM, F., X. VEKEMANS, P. MEERTS, E. GRATIA, and C. LEFEBVRE. 1997. Allozyme variation in relation to ecotypic differentiation and population size in marginal populations of Silene nutans. Heredity 78: 552-560.

VEKEMANS, X. and C. LEFEBVRE. 1997. On the evolution of heavy-metal tolerant populations in Armeria maritima: evidence from allozyme variation and reproductive barriers. J. Evol. Biol. 10: 175-191. 
SPI MAG TER can ONF TOS mon NER val tec MEZ DVL TOM SUB ORS PIA RIP CHI vel vig mal STI PIL val pop fua ant TRV BOT MIN LAG VJ2 POL VJ1

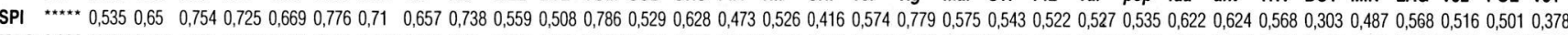

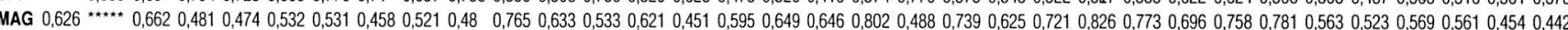

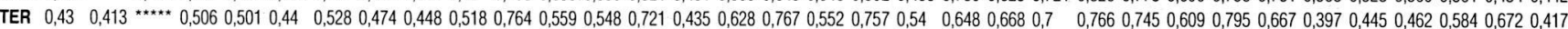

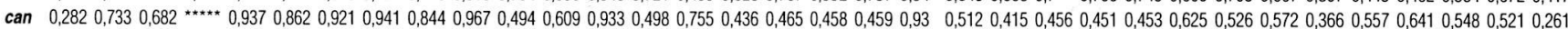

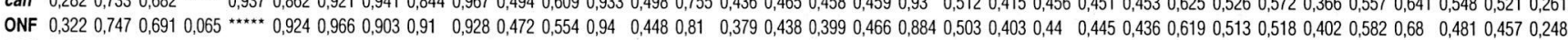

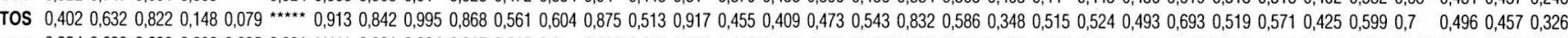

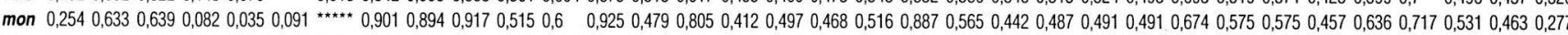

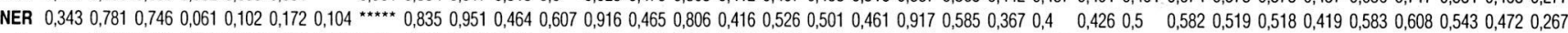

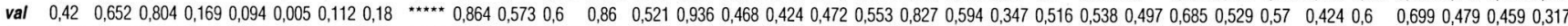

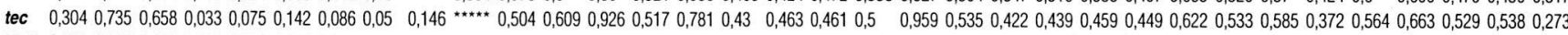

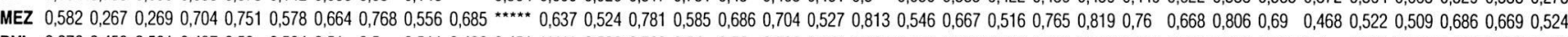

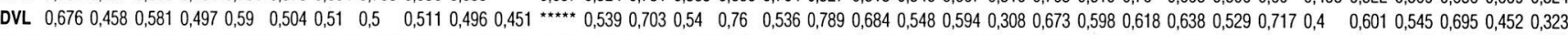

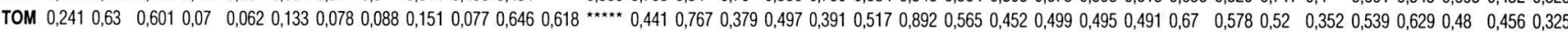

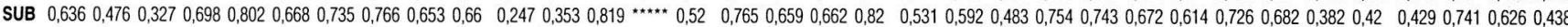

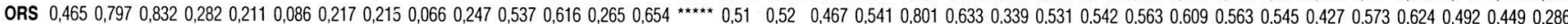

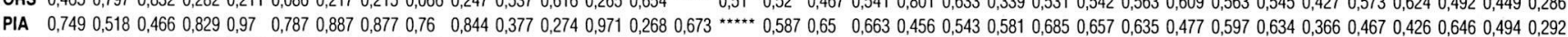

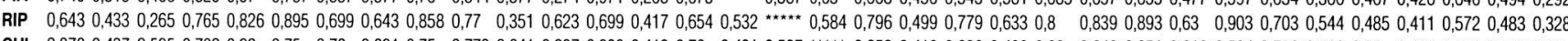

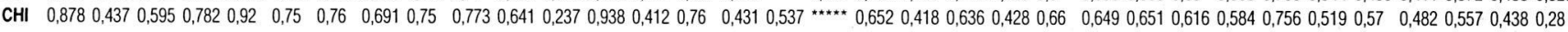

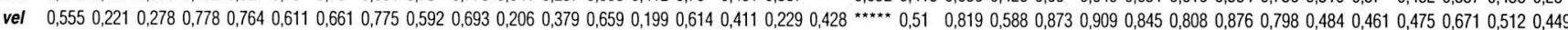

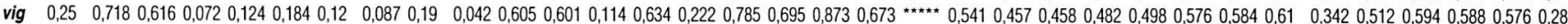

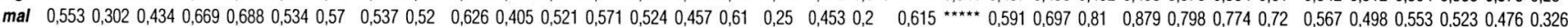

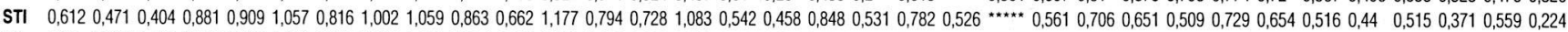

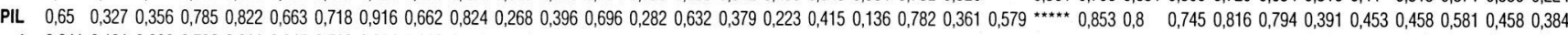

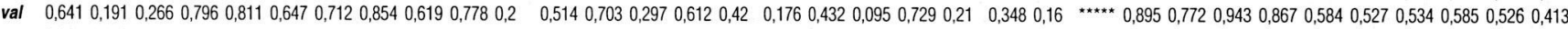

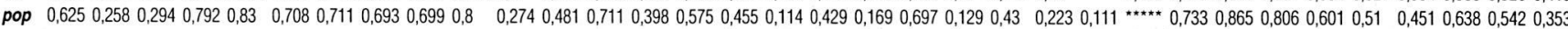

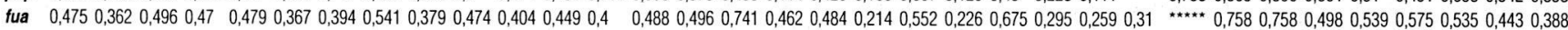

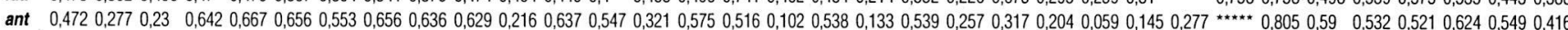

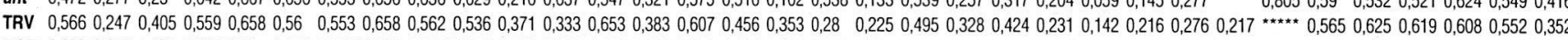

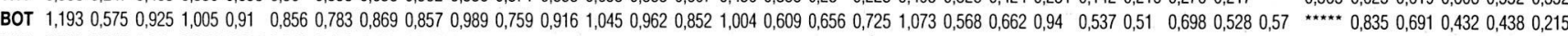

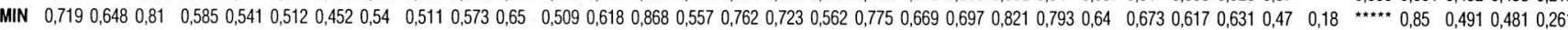

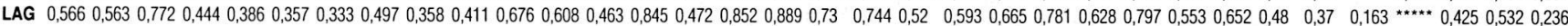

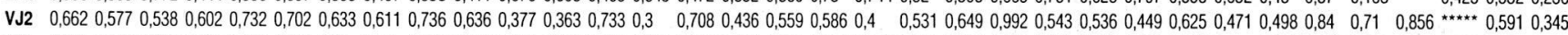

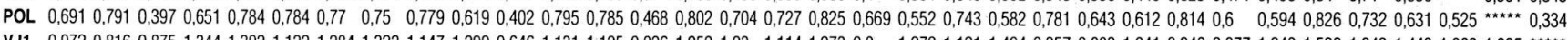

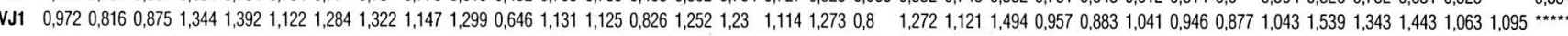

Genetic distance and genetic identity (Nei, 1972) below and above the diagonal, respectively. 